\title{
FORMULASI NANOEMULSI KOMBINASI EKSTRAK BUNGA MAWAR (Rosa damascena Mill.) DAN EKSTRAK UMBI BENGKUANG (Pachyrhizus erosus L.) MENGGUNAKAN MINYAK PEMBAWA VIRGIN COCONUT OIL (VCO)
}

\author{
Oppi Yolan Destiyana ${ }^{1, *}$, Hajrah ${ }^{1}$, Laode Rijai \\ Laboratorium Penelitian dan Pengembangan Kefarmasian "Farmaka Tropis", \\ Fakultas Farmasi, Universitas Mulawarman, Samarinda, Indonesia \\ *Email: oppiyolan20@ gmail.com
}

\begin{abstract}
Rose (Rosa damascena Mill.) and bengkoang (Pachirhizus erosus L.) extracts have long been used in the cosmetics field because it can brighten the skin and in order to increase its penetration and absorption through the skin it can be made in the form of nanoemulsion. The aim of this study was to formulate a combination of both extracts in nanoemulsion preparations and physical characterization including organoleptic, percent transmittance, particle size, and pH. Nanoemulsion consists of three main components, namely the oil phase, surfactant and cosurfactant formulated using the sonication method. The results showed that, the best formula for nanoemulsion combination of rose flower and bengkoang extract, is formula with VCO ingredients, Cremophor RH4O and PEG 400 (2: 7: 1) with transmitance percent $95.8 \%$, particle size $31.3 \mathrm{~nm}$, the polydispersibility index is 0.274 and $\mathrm{pH}$ is 5.33 .
\end{abstract}

Keywords: Bengkoang, nanoemulsion, rose

\begin{abstract}
ABSTRAK
Ekstrak bunga mawar dan umbi bengkuang telah lama dimanfaatkan dalam bidang kosmetik karena dapat mencerahkan kulit sehingga agar dapat meningkatkan penetrasi dan absorpsinya melalui kulit dapat dibuat dalam bentuk sediaan nanoemulsi. Penelitian ini bertujuan untuk memformulasi kombinasi kedua ekstrak tersebut dalam sediaan nanoemulsi kemudian dilakukan karakterisasi fisik meliputi organoleptis, persen transmitan, ukuran partikel, dan $\mathrm{pH}$. Nanoemulsi terdiri atas tiga komponen utama yaitu fase minyak, surfaktan dan kosurfaktan yang diformulasi menggunakan metode sonikasi. Hasil penelitian yang diperoleh adalah, formula terbaik untuk nanoemulsi kombinasi ekstrak bunga mawar dan umbi bengkuang yaitu formula dengan bahan VCO, Cremophor RH40 dan PEG 400 (2:7:1) dengan persen transmitan 95,8\%, ukuran partikel 31,3 nm , indeks polidispersibilitas 0,274 dan $\mathrm{pH}$ 5,33.
\end{abstract}

Kata Kunci : Bengkuang, bunga mawar, nanoemulsi

DOI: https://doi.org/10.25026/mpc.v8i1.331 


\section{PENDAHULUAN}

Bunga mawar dan umbi bengkuang banyak dimanfaatkan sebagai bahan dasar dalam pembuatan sediaan farmasi terutama dalam bidang kosmetik karena dapat mencerahkan kulit. Minyak atsiri mawar yang diekstrak dari bahan mahkota bunga dapat menjaga kelembaban kulit dan membantu menyamarkan kerutan pada kulit ${ }^{[1]}$. Umbi bengkuang mengandung senyawa golongan isoflavon yang telah diteliti aktivitasnya meliputi aktivitas menyerap sinar UV, antioksidan dan penghambatan enzim tirosinase ${ }^{[2]}$.

Kombinasi dari bunga mawar dengan bengkuang juga telah lama digunakan oleh masyarakat pedalaman di daerah Kalimantan Timur sebagai bahan dasar perawatan wajah untuk menghilangkan bekas jerawat. Sehingga, dalam penelitian ini dilakukan formulasi sediaan berupa nanoemulsi dengan bahan dasar kombinasi dari ekstrak bunga mawar dan umbi bengkuang. Sediaan nanoemulsi dipilih karena dapat mengingkatkan absorbsi dan penetrasi melalui kulit.

Nanoemulsi merupakan sistem penghantaran obat yang terdiri atas fase air dan minyak yang distabilkan oleh kombinasi antara surfaktan dan kosurfaktan dengan rata-rata droplet berukuran $<100 \mathrm{~nm}^{[3]}$. Berdasarkan uraian tersebut, maka dilakukan penelitian untuk memformulasi kombinasi ekstrak bunga mawar dan umbi bengkuang menjadi sediaan nanoemulsi dan mengetahui karakteristik fisik dari sediaan nanoemulsi.

\section{METODE PENELITIAN}

\section{Alat dan Bahan}

Alat yang diguanakan dalam penelitian ini yaitu botol vial, rotary evaporator Buchi, timbangan analitik Precisa XB 220A, magnetic bar, hotplate and stirrer STUART CB162, spektrofotometer $\quad U V$-Visible, PSA (Particle Size Analyzer) HORIBA SZ-
100, kulkas Panasonic, $\mathrm{pH}$ meter dan sonikator Krisbow.

Bahan yang digunakan dalam penelitian ini yaitu bunga mawar, umbi bengkuang, Petroleum eter, Metanol, Etil asetat, VCO, Cremophor RH40, Tween 80, PEG 400, Etanol $96 \%$ dan Aqua deion.

\section{Determinasi Tanaman}

Determinasi tanaman dilakukan di Laoratorium Dendrologi dan Ekologi Hutan Fakultas Kehutanan Universitas Mulawarman.

\section{Ekstraksi}

Sampel bunga mawar diperoleh dari kebun mawar di daerah Jl.M.T.Haryono Samarinda, sedangkan umbi bengkuang dikumpulkan dari daerah Separi Tenggarong seberang. Sampel selanjutnya disortasi dan dicuci bersih dengan air mengalir, kemudian dikeringkan dengan diangin-anginkan. Kemudian ditimbang masing-masing berat simplisia segar.

Mahkota bunga mawar 400 gram dimaserasi menggunakan pelarut etanol $96 \%$. Sampel kemudian disaring dan filtrat yang diperoleh dipekatkan menggunakan rotary evaporator pada suhu $50^{\circ} \mathrm{C}$ hingga diperoleh ekstrak kental lalu ditimbang.

Umbi bengkuang 2,2 kilogram yang sudah diiris tipis dikeringkan dengan oven suhu $60^{\circ} \mathrm{C}$, setelah kering selanjutnya sampel digiling. Umbi bengkuang yang sudah digiling lalu diekstraksi dengan metode soklet menggunakan pelarut petroleum eter. Residu selanjutnya diekstrak dengan metanol, ekstrak metanol umbi bengkuang lalu dipekatkan dengan rotary evaporator hingga diperoleh ekstrak metanol pekat umbi bengkuang. Dilanjutkan dengan proses fraksinasi menggunakan etil asetat hingga diperoleh fraksi etil asetat umbi bengkuang dan ditimbang berat fraksi. 


\section{Formulasi Nanoemulsi}

Dicampurkan ekstrak dengan VCO kemudian ditambahkan surfaktan cremophor RH40 dan tween 80 serta kosurfaktan etanol dan PEG 400 dengan variasi perbandingan sesuai pada tabel rancangan formula nanoemulsi. Kemudian dicampurkan menggunakan magnetic stirrer $(100 \mathrm{rpm})$ selama 1 jam dan dimasukkan dalam sonikator selama 30 menit. Campuran tersebut kemudian ditambahkan aqua deion perbandingan 1:5 dan diaduk kembali menggunakan magnetic stirrer hingga homogen. Lalu dilakukan karakterisasi fisik sediaan nanoemulsi.

\section{Karakteristik Fisik Nanoemulsi}

\section{Persen Transmitan (\%)}

Sediaan nanoemulsi dimasukkan ke dalam kuvet dan diukur persen transmitannya pada panjang gelombang $650 \mathrm{~nm}$ menggunakan spektrofotometri UV-Vis. Aqua deion digunakan sebagai blangko saat pengujian ${ }^{[4]}$. Formulasi yang memiliki persentase transmitan 90\%$100 \%$ menunjukkan bahwa formulasi tersebut memiliki penampakan visual yang jernih dan transparan ${ }^{[5]}$.

\section{Organoleptis}

Pengamatan organoleptis nanoemulsi dilakukan secara visual menggunakan panca indera, parameter yang diamati meliputi warna, bau, kejernihan, dan homogenitas.

\section{3. $\mathbf{p H}$}

Pengukuran $\mathrm{pH}$ sediaan dilakukan dengan menggunakan $\mathrm{pH}$ meter. Sebelum digunakan, elektroda dikalibrasi atau diverifikasi dengan menggunakan larutan standar dapar $\mathrm{pH} 4$ dan 7. Proses kalibrasi selesai apabila nilai $\mathrm{pH}$ yang tertera pada layar telah sesuai dengan nilai $\mathrm{pH}$ standar dapar dan stabil. Setelah itu elektroda dicelupkan ke dalam sediaan. Nilai $\mathrm{pH}$ akan tertera pada layar.

\section{Ukuran Partikel dan Indeks Polidispersibilitas}

Pengujian dilakukan dengan menggunakan PSA (Particle Size Analyzer) dengan tipe Dynamic Light Scattering. Sebanyak $10 \mathrm{ml}$ sediaan diambil dan dimasukkan ke dalam kuvet. Kuvet harus terlebih dahulu dibersihkan sehingga tidak mempengaruhi hasil analisis. Kuvet yang telah diisi dengan sediaan kemudian dimasukkan ke dalam sampel holder dan dilakukan analisis oleh instrumen. Data yang diperoleh yaitu, ukuran partikel dan nilai polidispersibilitas (distribusi ukuran partikel).

\section{HASIL DAN PEMBAHASAN}

\section{Determinasi Tanaman}

Hasil determinasi tanaman yang dilakukan di Laboratorium Dendrologi dan Ekologi Hutan Fakultas Kehutanan Universitas Mulawarman menunjukkan bahwa bunga mawar merupakan spesies Rosa damascena Mill dan umbi bengkuang merupakan spesies Pachyrhizus erosus L.

\section{Data Rendemen Ekstrak}

Ekstraksi bunga mawar menggunakan metode maserasi dengan etanol 96\% menghasilkan berat ekstrak sebanyak 201 gram dengan rendemen $50,25 \%$ dan untuk ekstraksi umbi bengkuang menggunakan metode sokhlet yang kemudian difraksinasi menghasilkan fraksi sebanyak 6,2 gram dan rendemen $4,062 \%$. Semakin tinggi nilai rendemen menandakan nilai ekstrak yang dihasilkan semakin banyak.

\section{Pemilihan Formula Terbaik}

Nanoemulsi merupakan sistem penghantaran obat yang terdiri atas fase air dan minyak yang distabilkan oleh kombinasi antara surfaktan dan kosurfaktann dengan rata-rata droplet berukuran $<100 \mathrm{~nm}^{[3]}$. Surfaktan dan kosurfaktan merupakan komponen penting dalam formulasi nanoemulsi. 
Surfaktan berperan dalam menurunkan tegangan antarmuka antara dua cairan yang ridak bercampur karena adanya gugus hidrofilik pada bagian kepala dan gugus hidrofobik pada bagian ekor ${ }^{[6]}$. Terdapat dua jenis surfaktan yang digunakan yaitu cremophor $\mathrm{RH} 40$ dan tween 80, kedua surfaktan ini termasuk surfaktan non ionik sehingga tidak akan mengiritasi kulit ketika digunakan. Kosurfaktan berperan dalam membantu kelarutan zat terlarut dalam medium dispers dengan meningkatkan fleksibilitas lapisan di sekitar area droplet dan menurunkan energi bebas permukaan sehingga stabilitas lebih dapat dipertahankan ${ }^{[7]}$. Selain itu dengan adanya penggunaan kosurfaktan, konsentrasi penggunaan surfaktan dapat dikurangi sehingga dapat mengurangi resiko iritasi yang dapat ditimbulkan ${ }^{[7]}$. Kosurfaktan yang digunakan dalam formula yaitu PEG400 dan etanol. Fase minyak dalam nanoemulsi berperan sebagai pembawa yang dapat melarutkan zat aktif yang bersifat hidrofobik. Fase minyak yang digunakan yaitu Virgin Coconut Oil (VCO) dan termasuk fase minyak yang sering digunakan dalam pembuatan nanoemulsi.VCO termasuk dalam long-chain triglycerides (LCT) karena mengandung rantai karbon lebih dari 12.

Nanoemulsi dapat terbentuk secara spontan maupun tidak spontan tergantung pada energi yang diberikan saat proses pembuatan. Penelitian ini menggabungkan dua metode tersebut karena dilakukan pencampuran fase minyak dan fase air secara perlahan dengan menggunakan strrer kemudian dibantu dengan metode sonikasi yang memanfaatkan gelombang ultrasonik untuk mengubah energi listrik menjadi getaran fisik yang dapat memperkecil ukuran partikel hingga $0,2 \mu \mathrm{m}^{[8]}$.

Tabel 3 Penggunaan terapi dirumah dan di Rumah Sakit

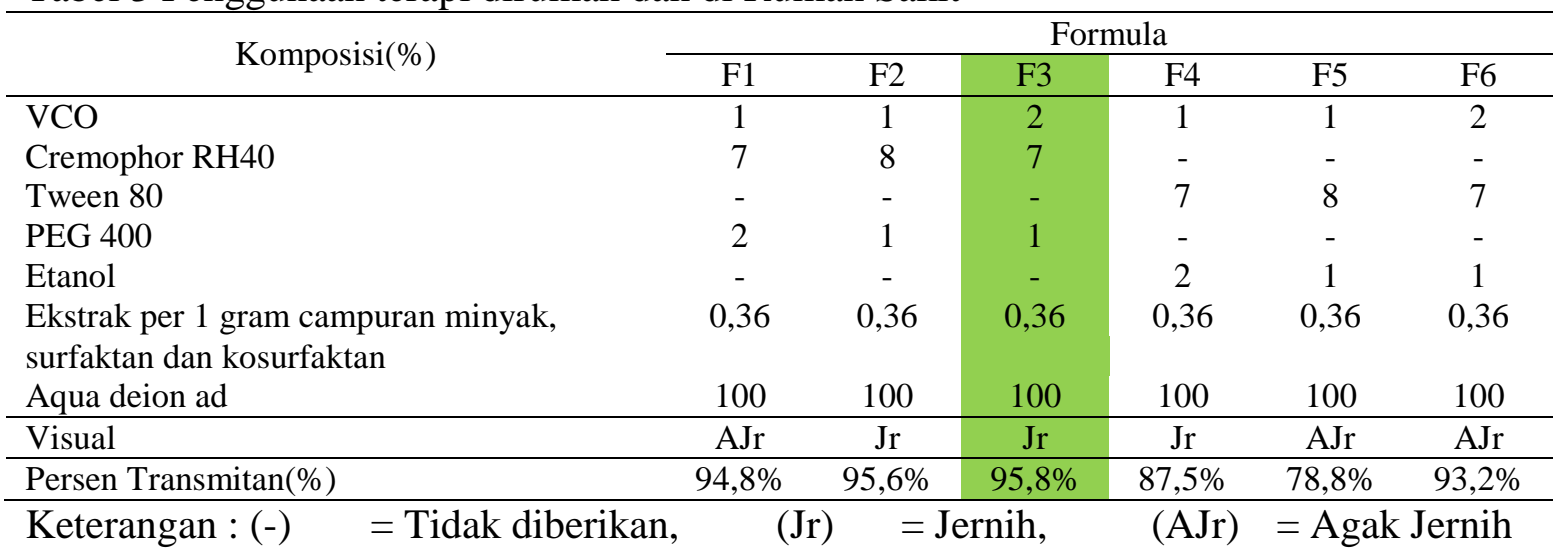

Tabel 2. Hasil Karakteristik Fisik Formula Terpilih

\begin{tabular}{llc}
\hline & Karakteristik Fisk & F3 VCP (2:7:1) \\
\hline \multirow{3}{*}{ Organoleptis } & Warna & Kuning Muda \\
& Kejernihan & Jernih \\
& Bau & Khas \\
& Homogenitas & Homogen \\
\hline \multirow{2}{*}{ PS } & & 5,33 \\
& Ukuran Partikel & $31,3 \mathrm{~nm} \pm 0,519$ \\
& Indeks Polidispersibilitas & $0,274 \pm 0,0195$ \\
\hline
\end{tabular}


Nanoemulsi diformulasi dengan variasi perbandingan antara minyak, surfaktan dan kosurfaktan yang telah ditentukan selanjutnya ditambahkan aqua deion sebagai fase air dengan perbandingan 1:5. Perbandingan kombinasi ekstrak bunga mawar dan umbi bengkuang yang digunakan dalam sediaan yaitu 1:3.

$$
\text { Formula terbaik dipilih }
$$

berdasarkan penampakan visual dan nilai persen transmitan. Persen transmitan menunjukkan tingkat kejernihan suatu sediaan cair yang dinyatakan dalam bentuk persen. Nanoemulsi yang baik memiliki penampakan visual yang jernih dan persen transmitan $90-100 \%$ atau mendekati dari persen transmitan air yaitu $100 \%$. Semakin besar nilai transmitan atau semakin jernih nanoemulsi maka dapat diperkirakan tetesan nanoemulsi telah mencapai ukuran nanometer. Ukuran fase terdispersi sangat mempegaruhi penampakan nanoemulsi. Bila sistem nanoemulsi memiliki ukuran globul sangat kecil dilewati cahaya, maka berkas cahaya akan diteruskan sehingga warna larutan terlihat transparan dan transmitan yang dihasilkan semakin besar. Aqua deion digunakan sebagai pembanding karena tidak memiliki partikel yang menahan transmisi cahaya sehingga akan meneruskan cahaya yang melewatinya tanpa adanya efek penghamburan cahaya sehingga mempunyai nilai transmitan $100 \%{ }^{[9]}$. Adapun hasil pemilihan formula terbaik dapat diliha pada Tabel 1.

Berdasarkan 6 rancangan formula yang telah dibuat, terdapat 4 formula yang memiliki persen transmitan 90$100 \%$ yaitu F1 $(94,8 \%), \mathrm{F} 2(95,6 \%), \mathrm{F} 3$ $(95,8) \%$, dan F6 $(93,2 \%)$. Kemudian dipilih lagi satu formula dengan nilai persen transmitan tertinggi yang akan dilanjutkan untuk karakterisasi fisik lainnya yaitu organoleptis, $\mathrm{pH}$, ukuran partikel, dan indeks polidispersibiltas. Didapatkan formula terbaik untuk nanoemulsi kombinasi ekstrak bunga mawar dan umbi bengkuang adalah formula 3 dengan komponen bahan VCO, Cremophor RH40 dan PEG 400 (2:7:1) karena memiliki visual yang jernih dan persen transmitan paling tinggi yaitu $95,8 \%$.

\section{Karakteristik Fisik Nanoemulsi}

Parameter untuk sediaan nanoemulsi dikatakan baik apabila memiliki penampakan jernih, tidak terjadi pemisahan fase dan homogen, nilai $\mathrm{pH}$ berada dalam rentang $\mathrm{pH}$ kulit yaitu 4-6, ukuran partikel < $100 \mathrm{~nm}$, dan indeks polidispersibilitas dibawah 0,5. Adapun karakteristik fisik formula sediaan nanoemulsi terpilih dapat dilihat pada Tabel 2.

Hasil pengamatan organoleptis menunjukkan formula 3 menghasilkan sediaan nanoemulsi yang berwarna kuning muda, jernih, bau khas dan homogen secara fisik. Nilai $\mathrm{pH}$ sediaan yaitu 5,33 dan berada pada rentang $\mathrm{pH}$ kulit sehingga dapat meminimalkan resiko iritasi saat penggunaan. Pengujian ukuran partikel dilakukan untuk melihat apakah sediaan nanoemulsi memiliki ukuran partikel yang memenuhi kriteria ukuran nanoemulsi yaitu $<100 \quad \mathrm{~nm}$. Pengukuran dilakukan dengan Particle Size Analyzer (PSA), adapun prinsip kerja alat ini adalah adanya hamburan cahaya yang terjadi akibat penembakan sinar laser mengenai partikel dalam sampel, cahaya yang dihamburkan mengenai partikel nanoemulsi sehingga sampel akan bereaksi menghasilkan gerak Brown, gerak acak tersebut akan dibaca oleh detektor foton pada sudut tertentu secara cepat sehingga dapat menentukan ukuran partikel, semakin kecil ukuran partikel maka akan semakin cepat gerakannya ${ }^{[10]}$. Hasil yang diperoleh yaitu sediaan nanoemulsi memilliki ukuran partikel 31,3 nm yang sudah masuk dalam kriteria ukuran partikel nanoemulsi dan indeks polidispersibilitas 0,274. Indeks polidispersibilitas menunjukkan keseragaman ukuran droplet pada sediaan 
dan untuk memperkirakan rentang distribusi ukuran partikel yang ada dalam suatu sampel serta mengetahui ada tidaknya agregasi, dimana semakin rendah nilai polidispersibiltas maka menunjukkan ukuran droplet yang seragam. Indeks polidispersibilitas yang baik memiliki nilai di bawah 0,5 sedangkan nilai diatas 0,5 menunjukkan bahwa distribusi globul tidak seragam ${ }^{[11]}$.

\section{KESIMPULAN}

Berdasarkan penelitian yang telah dilakukan, diperoleh formula terbaik untuk sediaan nanoemulsi kombinasi ekstrak bunga mawar dan umbi bengkuang yaitu formula dengan komponen bahan VCO, Cremophor RH40 dan PEG 400 (2:7:1) dengan karakteristik fisik persen transmitan $(95,8 \%)$, penampakan visual jernih, $\mathrm{pH}$ $(5,33)$, ukuran partikel $(31,3 \mathrm{~nm})$ dan indeks polidispersibilitas $(0,274)$.

\section{DAFTAR PUSTAKA}

[1] Yulianingsih, D. Amiarsih, R. Tahir dan Sabari S.D. 2006. Seleksi Jenis Bunga untuk Produksi Mutu Minyak Mawar. Jurnal Hortikultura 16 (4) : $345-348$.

[2] Lukitaningsih, Endang., et al. 2014. Bioactive Compounds in Bengkoang (Pachyrizus erosus) as Antioxidant and Tyrosinase Inhibiting Agents. Indonesian J. Pharm. Vol. 25. No.2 : 68-75. ISSN-p : 2338-9427.

[3] Fulekar, $\quad$ M.H., 2010. Nanotechnology : Importance and Applications. I.K International Publishing House Pvt.Ltd. Mwe Delhi, p.1.

[4] Pratiwi, L., A. Fudholi, R. Martien,S. Pramono. 2016. Design and Optimization of SelfNanoemulsifying Drug Delivery Systems (SNEDDS) of Ethyl Acetate Fraction from Mangosteen Peel
(Garcinia Mangostana, L.). International Journal of Pharm Tech Research. Vol. 9 (6). pp 380-387.

[5] Costa, J. A., Lucas, E. F., Queiros, Y. G. C., Mansur, C. R. E. 2012.Evaluation of Nanoemulsions In The Cleaning of Polymeric Resins. Colloids Surf Physicochem. Eng. Asp. 415.Pp. 112-118.

[6] Schramm, L.L. 2000. Surfactants: Fundamentals and Applications in the Petroleum Indsutry. Cambridge University Press. United Kingdom.

[7] Azeem, A., Rizwan, Ahmad, F.J., Iqbal, Z., Khar, R.K., Aqil, M., et al., 2009. Nanoemulsion Components Screening and Selection. A Technical Note, AAPS Pharm Sci Tech, 10(1):69-76.

[8] Gupta, P.K., Pandit, J.K., Kumar, A., Swaroop, P., and Gupta, S. 2010. Pharmaceutical Nanotechnollgy Novel Nanoemulsion: High Emulsification Preparation, Evaluation and Application. The Pharma Research, 3:117-138.

[9] Wahyuningsih, I., dan W. Putranti, 2015, Optimasi Perbandingan Tween 80 dan Polietilenglikol 400 Pada Formula Self Nanoemulsifying Drug Delivery System (SNEDDS) Minyak Biji Jinten Hitam, Pharmacy, 12(02): 223-241.

[10]Ristian, I., 2013, Kajian Pengaruh Konsentrasi Perak Nitrat (AgNO3) terhadap Ukuran Nanopartikel Perak, Skripsi, Jurusan Kimia, Fakultas Matematika dan Ilmu Pengetahuan Alam, Universitas Negeri Semarang: 11.

[11] Suciati, T., A. Aliyandi dan Satrialdi, 2014, Development of Transdermal Nanoemulsion Formulation For Simultaneous Delivery of Protein Vaccine And Artin-M Adjuvant, Int J Pharm Pharm Sci. 6(6): 536-546. 